Making Truth in Early Modern Catholicism 


\section{Scientiae Studies}

The Scientiae Studies series is a forum ideally suited to innovative interdisciplinary discourses and strands of intellectual history pivoted around the circulation of knowledge. The series is deliberately global, so looks beyond, as well as within, European history. And since it confronts theories and practices in the early modern period that had yet to be separated into their modern ,scientific configurations, the proposals we welcome study both learned societies and artisanal knowledge, as well as the history of universities and the birth and evolution of early modern collections. Thus we aim to bridge the gap between material culture and history of ideas. While natural philosophy and natural history remain central to its endeavours, the Scientiae Studies series addresses a wide range of related problems in the history of knowledge, which respond to the challenges posed by science and society in our changing environment.

Series editors

Stefano Gulizia, University of Milan (Editor-in-chief, 2020-2023)

Vittoria Feola, University of Padova

Christine Göttler, University of Bern

Cassie Gorman, Anglia Ruskin University

Karen Hollewand, Utrecht University

Richard Raiswell, University of Prince Edward Island

Cornelis Schilt, Linacre College, Oxford 


\title{
Making Truth in Early Modern Catholicism
}

\author{
Edited by \\ Andreea Badea, \\ Bruno Boute, \\ Marco Cavarzere, and \\ Steven Vanden Broecke
}


The publication of this book is made possible by a grant from Pro-Post-Doc-Programm am Forschungszentrum Historische Geisteswissenschaften der Goethe-Universität Frankfurt am Main, deutsches Historisches Institut in Rom, and Ghent University.
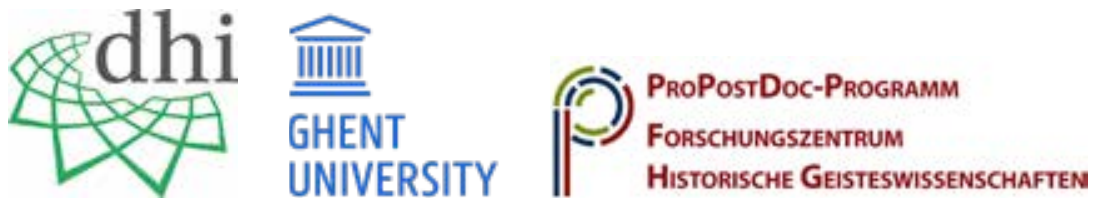

Cover illustration: Detail, Portrait of Galileo Galilei, 1885, by Edmond van Hove. Groeningemuseum Brugge; Musea Brugge (www.artinflanders.be, foto Dominique Provost).

Cover design: Coördesign, Leiden

Lay-out: Crius Group, Hulshout

$\begin{array}{ll}\text { ISBN } & 97894637205^{2} 6 \\ \text { e-ISBN } & 9789048550043 \\ \text { DOI } & 10.5117 / 97894637205^{26} \\ \text { NUR } & 685\end{array}$

(C) The authors / Amsterdam University Press B.V., Amsterdam 2021

All rights reserved. Without limiting the rights under copyright reserved above, no part of this book may be reproduced, stored in or introduced into a retrieval system, or transmitted, in any form or by any means (electronic, mechanical, photocopying, recording or otherwise) without the written permission of both the copyright owner and the author of the book.

Every effort has been made to obtain permission to use all copyrighted illustrations reproduced in this book. Nonetheless, whosoever believes to have rights to this material is advised to contact the publisher. 